O. Shvets

NNEGC «ENERGOATOM» Separate Entity «Khmelnitsky NPP, Safety analysis department, 20 Enerhetykiv Str., Netishyn, Ukraine, 30100; e mail: khnpp_2@ukr.net

\title{
ORGANIZATION OF COOLING POND OPERATION FOR ENSURING THE SAFE OPERATION OF THE ENERGY OBJECT
}

\begin{abstract}
О.П. Швець. Організація роботи водойми - охолоджувача як алгоритм безпечної експлуатації енергетичного об’єкта. На будь-якому енергетичному підприємстві обов'язково присутні системи охолодження та тепловідведення від головного енергетичного обладнання, таких як конденсатори, теплообмінники чи насоси. На АЕС таку функцію виконують системи циркуляційного водопостачання. У якості охолоджувача в цій системі можуть використовуватися градирні, бризкальні басейни чи водойма-охолоджувач (ВО). В наданій статті наведено аналіз ефективності алгоритму функціонування саме енергетичних водоймохолоджувачів. Ціллю наукового дослідження $є$ акцентування проблематики, що пов'язана із проектними розрахунками та недоліками будівництва, що негативно впливають на подальшу роботу енергетичного об'єкту. Об'єкт дослідження водоймаохолоджувач Хмельницької АЕС, що досліджується з урахуванням консервативного підходу. Під консервативним підходом мається на увазі підхід, при якому для параметрів і характеристик конструкції приймаються такі значення, використання яких призводить до виникнення найгірших показників функціонування системи чи ії відмови. Консервативні фактори: негативне вітрове навантаження, екстремальні температури та вологість навколишнього середовища, зменшення підживлення, погіршення перемішування, максимальне навантаження енергетичного об’єкту, тощо. Основною метою роботи є розробка заходів для підвищення ефективності роботи ВО. Наукова та практична цінність складається 3 того, що до розрахунків конструкції гідротехнічних споруд водойм-охолоджувачів пропонується ввести прогностичні розрахунки показників функціонування, що проявляються тільки після побудови об’єкту і потребують детального моделювання. В роботі досліджуються показники оптимальної роботи ВО енергетичного комплексу в спекотну пору року при врахуванні алгоритму функціонування гідротехнічного об'єкту як єдиної структури в залежності від зміни зовнішніх факторів та теплового навантаження. Враховуються додаткові негативні фактори впливу й додаткові, в консервативному сенсі, вихідні події техногенного та природного характеру. Проводиться детерміністичний аналіз функціонування системи, на різних рівнях навантаження.

Ключові слова: водойма-охолоджувач, атомна енергетика, теплообмін, тепловіддача, циркуляційне водопостачання
\end{abstract}

$O$. Shvets. Organization of cooling pond operation for ensuring the safe operation of the energy object. Any energetic company must have cooling and heat recovery systems from main energetic equipment, such as condensers and heat exchangers or pumps. At nuclear power plants, such a function is carried out by circulating water systems. Any cooling towers spray pools or pond-cooler. In the given scientific articles, from view for specified subject, functioning algorithm and efficiency of energetic ponds-coolers (P.C.) analysis is given. Purpose of scientific research is to emphasize a problems associated with miscalculations in design and installation calculations and disadvantages of construction, which adversely affect further actual work of the energy object. The object of studies is the cooling-pond of the Khmelnitsky NPP, which is studied with conservative approach. Under the conservative approach, we mean an approach in which for parameters and characteristics of the design such values are taken, the use of which leads to the worst performance of the system or its failure. Conservative factors: negative wind load, extreme temperatures and humidity of environment, reduction of feed, deterioration of mixing, maximum load of power facility, etc. The main purpose of works is to develop measures to improve efficiency of the P.C. The scientific and practical value is that it is proposed to introduce prognostic calculations of performance indicators into the calculations of the design of hydraulic structures of cooling reservoirs, which appear only after the construction of the object and require detailed modeling. The parameters of the optimal operation of ponds-coolers of the power complex in the hot season are analyzed, taking into account the algorithm of functioning of the hydro-engineering object as a single structure, depending on changes in external factors and changes in the heat load. Additional negative factors of influence and additional, in the conservative sense of the analysis, initial events of anthropogenic and natural character are taken into account. A deterministic analysis of the functioning of the system is carried out, with different load levels and the operation of additional systems for the cooling of circulating water.

Keywords: pond-cooler, atomic energy, heat exchange, heat transfer, circulating water supply system

Foreword. The projects of any energetic complex are destined for power generation includes the system of rotating water supply system and cooling of the condensers of the main power equipment. In depending on the geographical location and availability of water resources, the technical layouts can be ranged from spray-pools to bulk pond-coolers. The algorithm and faultless functioning is the main part of organization of reliable operation and efficient heat dissipation from energetic equipment.

DOI: 10.15276/opu.1.57.2019.08

(C) 2019 The Authors. This is an open access article under the CC BY license (http://creativecommons.org/licenses/by/4.0/). 
This article are contains an analysis of proposed organization algorithm for the operation of rotary water supply system, where research prototype is rotary water supply system of the Khmelnitsky NPP (this time and next - KHNPP), which include bulk P.C. The P.C. used as coolant storage for main turbine condensers and thermal power equipment of the enterprise.

The peculiarities of the hydrotechnical construction are that P.C. constructed with using a bulk water-retaining dam and the fact that P.C. is fine-rasted with a rotating circulation system. Additional feeding is provided, but is regulated by the time of year. At specified hydrotechnical object there are present aspects that worsen design performance and have a large amount of aspects for functioning improving, which can become a prototype for consideration and construction of same type of hydraulic engineering structures.

Formulation of the problem. Problem of items adduce is that of construction creation and research operation of hydrotechnical construction the factors of influence which are of natural or technogenic origin are not taken into account or unregulated changes of the technological process. Thus, for KHNPP P.C., the factors of "short circulation", which arose due to flaws in the construction design and climate change and heat load on surface of evaporation mirror, were not taken into account. As a result, at nominal load of industrial site an increase in average temperature of circulating water takes place in the hot season.

Analysis of last research and publications. Analysis of latest publications devoted the problems of functioning and algorithm of work of pond-coolers showed a lack of coverage subject. In [1], the optimization of the purge-fueled P.C. value is considered. In [2] the improvement of environmental monitoring is considered. In [3] mathematical modeling of Zaporizhzhya NPP P.C. is carried out. The problem of increasing cooling efficiency is not given.

At present time, only urgent experiments of hydrotechnical structures of energetic complex executed related with the modernization and reconstruction of industrial ground.

From relation to the prototype of experiments, research was carried on the improvement of functioning and removal of defects of existing design failures due to the planned completion of the construction of two energetic units of the KhNPP, with the installation of an electrical capacity of 2000 MW electrical.

Formation and setting of research objectives. The object of experiments is to increase the efficiency of the KHNPP P.C, in factors of reduced water resources and an increase in total capacity of energy complex combination with pathogenic factors influencing the hydraulic structure and development of corrective measures object at regulating water regime with negative influence of some factors.

Principle and algorithm of optimal functioning of pond-coolers. In exploitation of P.C. KHNPP, as in all individual cases, negative factors that have a local or existent distinctness to influence on functioning of object for under different load conditions, crossing of negative factors that pose a potential threat for stable operation of enterprise is present. Influence of these factors may be partially remove by taking corrective measures, building additional technical complexes and changing the operating regulations, for increasing of intensification of heat exchange level.

Improvement of P.C. working is possible by constructing of additional technological systems for cooling water and forming a flow in inside of the bulk, which will facilitate intensification of heat transfer from surface, taking into account all natural and pathogenic factors of influence, inherent in area of the object placement [4].

For determining of algorithm for optimal operation of P.C., in estimation of hydrotechnical structure, is necessary to take into account a range of factors that revealed with the intensification of human economic activity in region, such as: water resource consumption in the object location area, prognostic level of average temperature and humidity air over years and probabilistic increase heat transfer from P.C. surface, including coercive measures that improve heat transfer. Composition analysis of forecast deterioration of water availability and forecast of increase average air temperature associated with human activities and climate changing [5]. 
In accordance to object design documentation of experimental object (this time and next - ODD), the prototype of experiments has an area of mirror, under conditions of normally-supported filling level is 20 Sq.km. and total volume of 120 millions $\mathrm{m}^{3}$ [6].

Useful volume, which calculated for functioning of four power-cells in the long run, is 80 millions $\mathrm{m}^{3}$. Predicted needs of KHNPP in the water cooler vary in range of $57 . .74 .6$ millions $\mathrm{m}^{3} /$ year, and summer consumption of four perspective (two working and two projected) power-cell will be $37.2 \ldots 40$ millions $\mathrm{m}^{3}$. Primary part of cooler (on average mean, about 40 millions $\mathrm{m}^{3}$ ) provides from main influx of "Hnylyi Rih" river. The rest of the necessary volume is taken by "Horyn" river and flow of soils, precipitation and reflux through of purified water from peeled purpose of the "satellite" city.

The actual maximum temperature average of environment, during of hot season, in zone of KHNPP located, reaches $33 \ldots 36{ }^{\circ} \mathrm{C}$ with a maximum registered index of $41.2{ }^{\circ} \mathrm{C}$. Indicated level of precipitation for summer season ranges from 61 to $247 \mathrm{~mm}$. At the same time, average temperature values of circulating water at the water intake line, during for summer season, are $29.5 \ldots 33.5^{\circ} \mathrm{C}$, under the nominal load of two existing and working power-cell. It is on verge of violation indicators of powercell safe operation, where the limit value for the parameters of circulating water supply is $33^{\circ} \mathrm{C}$ [7]. When two additional power-cells of typical PWER-1000 will be completed and commissioning, the average temperature values of circulating water will be $39.7 \ldots 42.3^{\circ} \mathrm{C}[6]$.

At industrial zone of KhNPP have a prevailing negative wind influence, which promotes to dumping of undervolished circulating water mass, to the water intake zone of main turbine condensers, which located on the north-eastern part of the reservoir construction. The same time, wind influence is mainly indicated in values of rumble directions: $55 \ldots 60 \%-\mathrm{W}-\mathrm{NW}-\mathrm{SW}, 25 \ldots 30 \%-\mathrm{S}-\mathrm{SW}$, $10 . .20 \%-\mathrm{E}-\mathrm{SE}$ and $\leq 5 \%$ is calm influence. That during rumble indicators of W-NW-SW, leads to increase in the average temperature of circulating water at intake point and intersection of regulatory limit of safe operation for circulation system. Thereby declining of indicators of KHNPP heatexchange equipment is observed [6, 7].

One of the factors that could lead to deterioration in operational reliability and efficiency of P.C. is the lack of design methods and computer programs for calculating predictive mode of operation. Modern mathematical models [3] allow calculating the movement of circulation masses along profile and middle of reservoir and determining value of cooled water temperature.

The mathematical model used in research is designed to calculate the fields, velocities and temperatures of water masses moving in a shallow cooling pond used in circulating water supply system of the Khmelnitsky NPP. The study of flow regime is carried out by calculating characteristics at a point, on the vertical, along the profile of the entire water reservoir area. The method is based on empirical relationships or theoretical hydrodynamic dependencies.

The study of flow regime is briefly summarized as follows: the function of total flows $\psi$, that is current function of integral water transfer, is determined by the equation:

$$
\frac{\partial}{\partial x}\left(\frac{A_{z} \partial \psi}{H^{3} \partial x}\right)+\frac{\partial}{\partial y}\left(\frac{A_{z} \partial \psi}{H^{3} \partial y}\right)=\frac{1}{2} \operatorname{rot}_{z} \frac{T}{H},
$$

where is $H$ - depth of the reservoir;

$A_{z}$ - coefficient of vertical turbulent exchange;

$\operatorname{rot}_{z} T=\frac{\partial T_{y}}{\partial x}-\frac{\partial T_{x}}{\partial y}-$ whirlwind of tangential wind stress;

$T_{x}$ and $T_{y}$ is the components of the tangential wind stress along the $x$ and $y$ axes, which are determined by the formulas:

$$
T_{x}=\gamma_{b} w_{x}|w| ; \quad T_{y}=\gamma_{b} w_{y}|w|,
$$

where $\gamma_{b}$ - wind friction parameter, taken equal to $3.25 \cdot 10^{-6}$;

$|w|$ - wind module; 
$w_{x}$ and $w_{y}$ - wind components along the ordinates.

The function of total flows which associated with dynamic slopes of reservoir surface by relations:

$$
\begin{aligned}
& \frac{\partial \xi}{\partial x}=-\frac{3 T_{x}}{2 g \rho H}-\frac{3 A_{z}}{g \rho H^{3}} \frac{\partial \psi}{\partial x}, \\
& \frac{\partial \xi}{\partial y}=-\frac{3 T_{y}}{2 g \rho H}-\frac{3 A_{z}}{g \rho H^{3}} \frac{\partial \psi}{\partial y},
\end{aligned}
$$

where $\frac{\partial \xi}{\partial x}$ and $\frac{\partial \xi}{\partial y}$ - slopes along the $x$ and $y$ axes;

$g$ - gravitational acceleration;

$\rho$ - water density.

Horizontal components of flow velocity along $x$ and $y$ axes ( $u$ and $v$, respectively) which determined from values of dynamic slopes:

$$
\begin{aligned}
& u=\frac{T_{x}}{A_{z}}(H-Z)+\frac{\rho g\left(H^{2}-z^{2}\right)}{2 A_{z}} \frac{\partial \xi}{\partial x}, \\
& v=\frac{T_{y}}{A_{z}}(H-Z)+\frac{\rho g\left(H^{2}-z^{2}\right)}{2 A_{z}} \frac{\partial \xi}{\partial y},
\end{aligned}
$$

where $z$ - is depth of calculated horizon.

Valuation of total field flows reduced to solution of equation (1) in finite-difference form by relaxation method. In this case, the function value of total flows at boundary points (on reservoir contour) is taken to be equal to zero. At liquid boundaries, that is, through areas where is water take temperature exchange, values correspond to the value of inflow or outflow. According to equations (4) and (5), the values of slope of water surface and flow velocity at individual horizons.

With real system using of equations (2) - (5), refined parameters and conditions. In particular, when determining the coefficient of vertical turbulent exchange, by used formula:

$$
A_{z}=\frac{\gamma_{b}}{4 \rho \alpha_{0}}
$$

where is $\alpha_{0}$ - wind current difference coefficient, equal to 0.0125 .

In this case, we mean ratio between the wind speed and speed of drift flow caused by it in its pure form, that is, in deep water.

Also, for numerical simulation of reservoirs, a computational grid has been created, built horizontally by curvilinear, non-uniform rectangular grid, which makes it possible to correctly describe flows in regions of complex.

Visualization of mathematical model of circulating water movement along unmodified KNPP P.C. water mirror with negative wind loads is shown in Fig. 1, where numerical values (by Celsius degrees) indicate the conditional boundary of temperature field in cooling pond.

Following by Fig. 1, a partial visualization of mathematical model KHNPP P.C. operation under degraded weather conditions and negative wind load, it can be seen that extension of temperature fields runs in reduced circle with reduced transport path and time. This leads to undercooled water flows and, as can be seen from the obtained numerical values, ingress of "hot" circulating water to water intake line of pumping stations condensers of main turbines. From obtained results it can be seen that approximately $65 . .70 \%$ of P.C. surface is effectively used, which is caused by design errors.

In the matter of man-made factors which deteriorating of operation indicators of KHNPP P.C., it is necessary to note of regulatory restrictions on water supply replenishment of P.C. [8] and technical incompleteness of hydro-technical construction, in the absence of a water-flow current-steering dam $[6,7]$. The main water-retaining dam has of due to filtration water passage, which have affects 
not only to work of P.C., but also has a harmful effect on the complex as a whole. The actual thermal emission from two operating power units is $4315.7 \mathrm{GCal} /$ year and $~ 8631.4 \mathrm{GCal} /$ year. Irrevocable consumption for evaporation and filtration is about $27 . .53$ million $\mathrm{m}^{3} /$ year, which will increase with the addition of two power units.

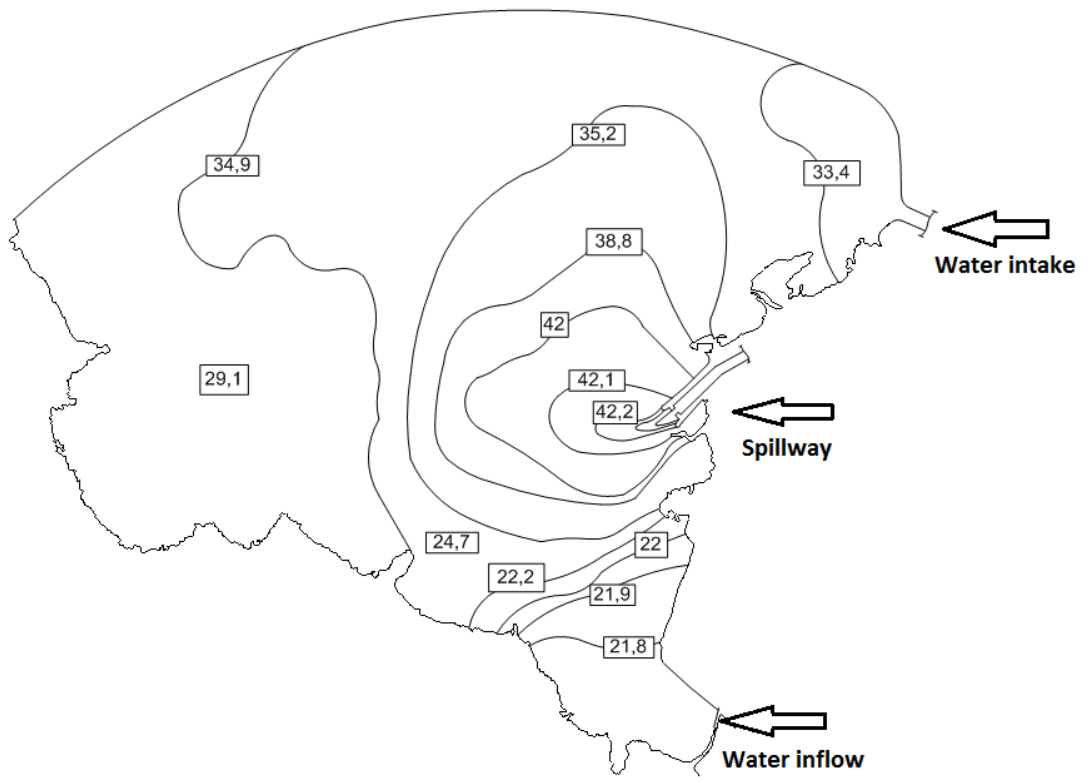

Fig. 1. Temperature fields of the KHNPP P.C. according to existing construction

Similar indicators of operation and results of analysis in the conditions of capacity doubling of industrial location, and, consequently, increasing the thermal load, endanger principles of safe operation of energy complex as a whole. Increase of thermal load by $50 \%$ leads to an excess of regulated limit $\left(33{ }^{\circ} \mathrm{C}\right.$ ) of cooled water by $6.7^{\circ} \mathrm{C}$, with an increase of $100 \%$ there will be an increase of $9.3^{\circ} \mathrm{C}[6]$.

The specified variations of indicators and analysis results show that there is need for taking corrective measures in the main operation modes and construction of complexes which consigned to cooling of circulating water masses $[4,5]$.

In time of creating the functioning P.C algorithm, the determination of design indicators should be carried taking into approaches of maximum conservatism account, in terms of worsening performance and increase in load [7].

The bottom relief and effective drainage area should be designed in such a way that trajectory of "hot"-runoff currents has a deviation not more than $7 \ldots 10 \%$ of total volume from discharge mass, depending on mass index and flow velocity, allowing the water to be transported across entire perimeter of P.C. mirror. The efficiency area using of P.C. mirror should not be lowered below $85 \%$ of available filling level, which will increase transport cooling time. Mixing and fracture laminar flow rate should reach about $90 \%$ of total weight of watercourse, which will provide more intense heat transfer during less transport time. Numeric value of P.C. operation efficiency increasing, taking into account of use above principle, will fluctuate within $11 . . .17 \%$ over the actual value.

In the current structure of energy enterprises P.C. trajectory deviation is in range of $27 . . .42 \%$, efficiency area using mirror varies within $63 . . .92 \%$ (depending on P.C. geometry and their sizes), fracture laminar flow coefficient does not exceed $43 \%$. This leads to decrease in efficiency of heat transfer from P.C. mirror area and does not exceed values of effectiveness using from $77 . . .78 \%$ of project mean.

Geometry and construction of P.C. (tributaries, drainage and water intake) should be designed in such a way that prevailing wind load and bottom terrain indices do not adversely affect to transport time and flow distance reduction. Optimal mode of operation cooled circulating water transport path and maximal calculated use coefficient of pond area should be chosen. 
In this Research Article discusses the option of bottom topography changing and building underwater part of stream-directing dam with a partial deepening of reservoir water area. Conducted variant calculations of bottom relief. Corresponding data were entered in mathematical model of hydraulic structure (1) - (7) and in mathematical grid of object coordinates. These structural changes is proposed to made by soil infliction and sand masses, raised directly from shallow sections of bottom of reservoir. It will ensure deepening of water area and reduce flow velocity. As a result of variant calculations was found optimal deepening amounts to $1.5 \ldots 2.5 \mathrm{~m}$. additionally in areas of P.C. with depths from 1 to 3 meters. The optimization criterion was in minimum value of temperature of cooled circulating water at the point of water intake with P.C. Further deepening does not have a significant effect on reducing the temperature, and therefore is not economically feasible. After carrying of these works on dredging, total area of deep-water zones will increase by $40 \%$.

The length of stream-directing dam, which taken into in mathematical model, is $600 \mathrm{~m}$. Body of this dam is designed in such a way that its crest is one meter below the prescribed water level with a normally-backed state of P.C. (203 meters above the Baltic Sea level). The dam design provides direction of $60 . .65 \%$ of the main spillway mass to stagnant zones of reservoir. Protection of dam against sand leaching with high waves and main stream energy of spillway is carried out by part stream passing through crest of structure.

With the help of developed mathematical model (1-7), course calculation of heat exchange process and water circulation after injection proposed changes in relief and design of reservoir according to most conservative conditions was carried out.

In the time of modeling KHNPP P.C., optimal characteristics of bottom relief were obtained, in temperature fields (Fig. 2) is more consistent with task. When using specified mathematical model and provided that stream-directing dam is taken into account and bottom is deepened, the following results are obtained: deviation of trajectory is $19 . .21 \%$, mirror surface using is $72 . .77 \%$ (depending on direction and strength of wind), laminarity failure ratio $~ 58 . .61 \%$, efficiency surface using of mirror $~ 73 . . .79 \%$.

The numerical value of temperatures in Fig. 2 is significantly lower than previous ones, which significantly infuse safe operation of heat exchanging equipment of NPP.

For conditions without using of negative wind load, effective use of cooling area is 85-90\%, and efficiency of heat exchange increases by $3 \ldots 40 \%$. A first visual result is visible when comparing Fig. 1 and Fig. 2.

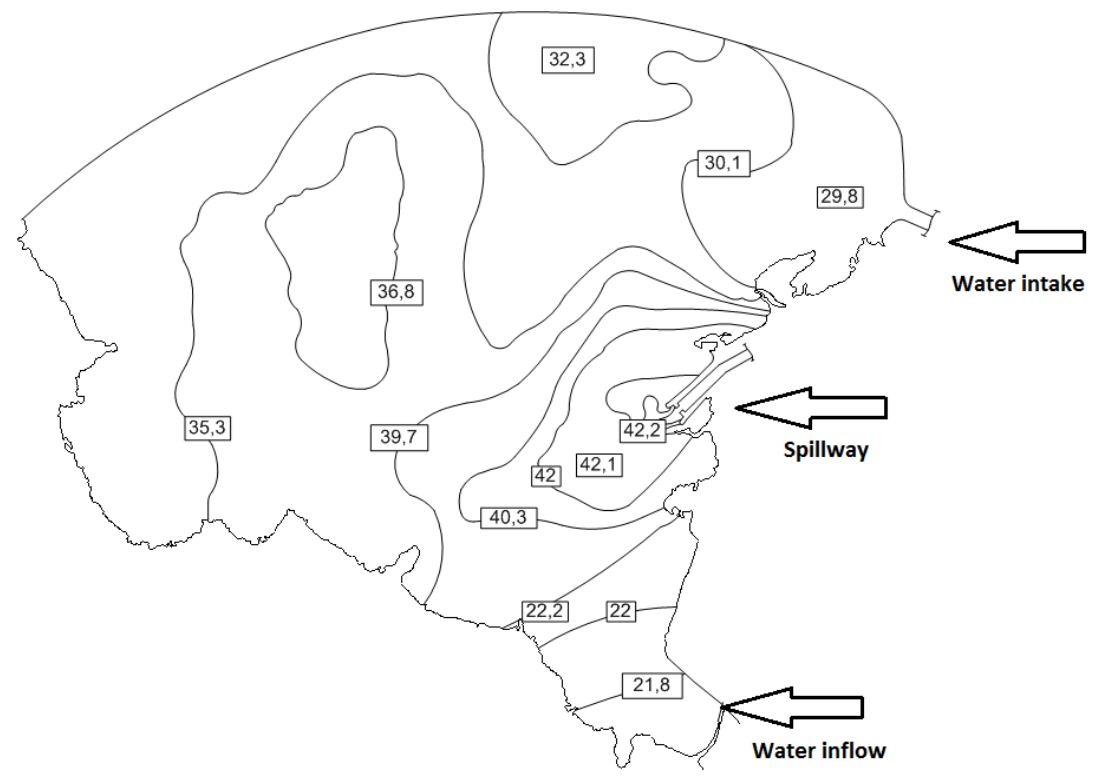

Fig. 2. Temperature fields in KHNPP P.C. taking into account with stream-directing and negating wind load 
As can be seen from Fig. 1, along profile of KNNPP P.C. there is reduced circulation of water masses that did not have time to get rid of excess thermal energy and have reduced circulation contour.

With a help of developed mathematical model (1-7) and isotherm obtained with it (Fig. 2), it is seen that circulation contour has improved and temperature indices of circulating water is reduced. The P.C. improvements proposed in the Article make it possible to reduce temperature of circulating water supply for conservative operating conditions by an average of $3^{\circ} \mathrm{C}$ degrees. And provided that were taken to calculate these isotherms, maximum reduction in circulating water was $3.6^{\circ} \mathrm{C}$.

After taking into account of mathematical model of deepening bottom and building a dam in KHNPP P.C. water area, the average circulating water temperature within $27.4 \ldots 30.2^{\circ} \mathrm{C}$ was obtained according to conservative conditions. This value fully meets conditions of safe operation and requirements of regulatory limits for circulating water supply. This result takes most conservative approaches to indicators of atmospheric temperature and effects of negative wind load.

\section{Conclusions}

Obtained results of calculations show that most negative phenomena in the aspect of P.C. efficiency operation are due to errors in design, where are not taken into account during design and creation of physical functioning algorithm as well as load changes and changes in climatic indicators.

In the basis of constructed P.C.-s does not put in conservative approach in choosing achievement of real indicators of operation hydraulic engineering. Factors for mixing streams and increasing transport time are not taken into account.

Mathematical model of reservoir-cooler functioning has been developed. Simulation of P.C. operation in actual state showed low efficiency of P.C. using, which coincides with actual data.

To improve efficiency of operation and increase reliability of heat exchange equipment, it has been proposed to bottom deepen of P.C. and use a water-retaining dam. When applying these proposals, namely, with optimal deepening of P.C. and using 600-meter dam, the efficiency of using rotating P.C. of energetic complex can be increased by $11 \ldots 17 \%$.

\section{Література}

1. Кравченко В.П., Мороз В.А. Послуги із забезпечення техногенної безпеки водойми-охолоджувача AЕC за рахунок організації раціонального режиму обміну води шляхом продувки-підживлення та біолого-хімічного моніторингу. The Scientific Heritage. 2018. № 21, part 1. P 61-67.

2. Moroz V. Ecological monitoring of water quality for NPP turnaround water supply systems. East European Scientific Journal. 2016. № 12, part 2. P. 92-98.

3. Беженар Р.В., Мороз В.А., Мороз Н.А. Адаптація тривимірної чисельної моделі «Тритокс» для прогнозування гідрохімічного режиму водойми-охолоджувача Запорізької АЕС. Промислова теплотехніка. 2013, .35, № 3. С. 30-38.

4. Швець О.П., Мирошниченко С.Т. Модернізація відвідних каналів ставків-охолоджувачів ТЕС і AEC з метою введення їх в цикл охолодження на прикладі Хмельницької АЕС. Збірник наукових праць СНУЯЕтаП. 2012. №4 (44). С. 66-74.

5. Швець О.П., Кравченко В.П.. Аналіз граничних можливостей та методів підвищення ефективності водойми-охолоджувача Хмельницької АЕС. Збірник доповідей V МНПКї «Безпека та ефективність атомної енергетики», 5-9 вересня 2016 р. Одеса. Одеса : ВМВ, 2017. С. 56-62.

6. Техніко-економічне обгрунтування спорудження енергоблоків № 3, 4. Том 13. Оцінка впливу на навколишне середовище. Частина 7. Поверхневі води., № 43-814.203.004.ОЭ.13.07 2012. Київ, 230 с. URL: http://www.noe.gv.at/noe/Umweltschutz/U_707_Energoatom_Kap7.pdf.

7. Техніко-економічне огрунтування спорудження енергоблоків № 3, 4. Том 13. Оцінка впливу на навколишнє середовище. Частина 13. Оцінка впливу на навколишнє середовище., № 43814.203.004.ОЭ.13.13 2012. Київ, 58 с. URL: http://www.noe.gv.at/noe/Umweltschutz/U_707_ Energoatom_Kap13.pdf.

8. Техніко-економічне огрунтування спорудження енергоблоків № 3, 4. Том 13. Оцінка впливу на навколишнє середовище. Частина 8. Підземні води. Книга 1. Пояснююча записка., № 43814.203.004.OЭ.13.08.01 2012. Київ, 137 с. URL: http://www.noe.gv.at/noe/Umweltschutz/U_707_ Energoatom_Kap8.pdf. 


\section{References}

1. Kravchenko, V.P. \& Moroz, V.A. (2018). Services for ensuring technological safety of reservoir-cooler of NPP due to organization of rational mode of water exchange by purge-feeding and bio-chemical monitoring. The Scientific Heritage, 21, 1, 61-67.

2. Moroz, V. (2016). Ecological monitoring of water quality for NPP turnaround water supply systems. East European Scientific Journal, 12, 2, 92-98.

3. Bezenar, R.V., Moroz, V.A. \& Moroz, N.A. (2013). Adaptation of three-dimensional numerical model “Tritoks” for prediction of hydrochemical regime of Zaporizhzhya NPP reservoir-cooler. Industrial heat engineering, 35, 3, 30-38.

4. Shvets, O.P. \& Miroshnichenko, S.T. (2012). Modernization of spillway channels of cooling-pounds WPPs and NPPs to enter them into cooling cycle on example of Khmelnitsky NPP. Collection of scientific works SNUNEI, 4, 44, 66-74.

5. Shvets, O.P., \& Kravchenko, V.P. (2017). Analysis of boundary possibilities and methods of increasing the efficiency of reservoir-cooler of Khmelnitsky NPP. Safety and efficiency of nuclear energy: Collection of reports V ISPC, (September 5-9, 2016). (pp. 56-62). Odesa: Ukraine.

6. № 43-814.203.004.ОЭ.13.07 Feasibility study for construction of power units № 3, 4. Volume 13. Environmental Impact Assessment. Part 7. Surface water. (2012). (p. 230) Kiev: Ukraine. Retrieved from: http://www.noe.gv.at/noe/Umweltschutz/U_707_Energoatom_Kap7.pdf.

7. № 43-814.203.004.ОЭ.13. Feasibility study for construction of power units № 3, 4. Volume 13. Environmental Impact Assessment. Part 13. Environmental Impact Assessment. (2012). (p. 58). Kiev: Ukraine. Retrieved from: http://www.noe.gv.at/noe/Umweltschutz/U_707_Energoatom_Kap13.pdf.

8. № 43-814.203.004.ОЭ.13.08.01. Feasibility study for construction of power units № 3, 4. Volume 13. Environmental Impact Assessment. Part 13. Underground water. Book 1. Explanatory note. (2012). (p 137) Kiev: Ukraine. Retrieved from: http://www.noe.gv.at/noe/Umweltschutz/U_707_Energoatom_Kap8.pdf.

Швець Олександр Петрович; Shvets Oleksandr, ORCID: https://orcid.org/0000-0003-4930-6206

Received January 24, 2019

Accepted May 15, 2019 